\title{
School Management Mechanisms and Control of Discipline among Pupils in Primary Schools: An Analysis of Discipline in Upper Primary Level
}

\section{Matovu Musa}

$\mathrm{PhD}$. Senior Lecturer, Affiliated Institution, Faculty of Education, Islamic University in Uganda, matovumousa@yahoo.com,m.matovu@iuiu.ac.ug

\section{Atim Agnes Martha}

Affiliated Institution, Faculty of Education, Islamic University in Uganda, marthaatim1 @ gmail.com

\begin{abstract}
The aim of the study was to analyse the effect of school management mechanisms on the discipline of pupils in upper basic primary level. This study examined the effect of; (a) guidance and counselling on the discipline of pupils, (b) school-rules and regulations on the discipline of pupils, and (c) school-family initiative program on the discipline of pupils in upper primary basic level. A cross sectional survey design using both quantitative and qualitative approaches was adopted to obtain data from a sample of 291 participants from 11 primary schools. Both the Statistical Package for Social Sciences (SPSS) and thematic content analysis for quantitative and qualitative data analysis respectively, were used. The effect results highlighted by the multiple regression for guidance and counselling and discipline were; $\mathrm{r}=0.628$; $\mathrm{p}$-value, $0.003<0.05$; $95 \%$, school rules and regulations and discipline were; $r=0.671 ; p$-value, $0.009<0.05 ; 95 \%$, and school-family initiative and discipline were; $r=0.601 ; \mathrm{p}$-value, $0.004<0.05 ; 95 \%$. It was concluded that guidance and counselling, school rules and regulation, and school-family initiative were significant predictors of pupils' discipline in upper primary basic level. It is recommended that school management should be committed in executing school management mechanisms in their hierarchy of importance to effectively implement discipline in upper primary basic level.
\end{abstract}

Keywords: school management mechanisms, discipline, upper primary basic level, control of discipline, primary school, analysis of discipline

\section{INTRODUCTION}

For discipline to prevail among pupils in any school, school set mechanisms should be fully functional and also known to the learners. School management mechanisms play a significant role in shaping pupils in terms of discipline inside and outside the school premises (INTO, 2004; de la Iglesia \& Castro Solano, 2018; Wagner \& Ruch, 2015; Blazar \& Kraft, 2017). According to Irkhin and Bogacheva (2015) school management mechanisms refer to a dynamic system that features the interrelation of the functions of interschool management and content procedure aspects of the educational systems. School management has the obligation to ensure that all members in the school play a role in the daily reinforcement of appropriate social habits among pupils in schools without compromising their rights (Mather \& Goldstein, 2001; O'Brennan, Bradshaw \& Furlong, 2014). School management mechanisms also refer to a management framework that is school-based, studentcentered and quality focused that provide schools with enhanced flexibility and autonomy in managing their own operation and resources for schools' development (Nooruddin \& Baig, 2014). Reid (2009) defined school mechanisms as operational procedures that are to be, or followed in a school

Citation: Musa, M., \& Martha, A. A. (2020). School Management Mechanisms and Control of Discipline among Pupils in Primary Schools: An Analysis of Discipline in Upper Primary Level. Anatolian Journal of Education, 5(1), 116. https://doi.org/10.29333/aje.2020.511a 
environment. In schools, school management mechanisms include the rules and regulations that the pupils must observe while at school, the guidance and counseling given to the pupils by the teachers and other senior members in the school, and the initiative between parents and the school, among others (Okeke, 2014; Dickinson, 2001; Donovan, 1998).

School management refers to the act of planning, organizing and controlling of a school's resources including pupils. If not well managed school management can be bogged down by dire disciplinary management issues if there are no proper mechanisms (Daggett, 2014; Redempta, 2010). Ensuring discipline in schools there should be a 'water tight' system that is governed by 'frugal' and contextualized school management mechanisms. This is because indiscipline among students has great effect on both their academic and social life (Gyan, et al, 2015; Ofori, Tordzro, Asamoah \& Achiia, 2018; Ngwokabuenui, 2015; De Witt \& Lessing, 2013; Ncontsa \& Shumba, 2013). School management mechanisms should be able to manage disruptive children behavior and those who violet school rules and regulations. Disruptive behaviours of children not only affect their fellow pupils but also their teachers by bringing about high stress levels among educators (Duncan-Williams, 2015; Orpinas \& Horne, 2004; Parsonson, 2012; Nooruddin \& Baig, 2014). There is need of having school management committees to play a role in the management of pupils' discipline in schools (Nzoka \& Orodho, 2014). This would be done by establishing school mechanisms and infrastructure such as a school fence and access points in order to limit movement, and running away of pupils from school (Karuri, 2015).

Currently, school management mechanisms have 'gone to the dogs' since the introduction of Universal Primary Education in schools. Through the Ministry of Education and Sports the government provides for Parent-Teacher Associations (PTAs), Board of Governors (BoGs) and School Management Committees (SMCs) as institutional frameworks for controlling discipline among students. In many parts of the country schools do not have update school management mechanisms to bring about good disciplinary management among pupils (NCSE, 2013; Korpershoek, Harms, de Boer, van Kuijk, \& Doolaard, 2014). In schools were school management mechanisms have been instituted they have been limited due to the diversity of pupils in terms of religions, culture and social back grounds (UNESCO, 2009; British Council, 2010; UNESCO \& UNICEF, 2007). The multicultural setting has been noted to have an effect on upbringing of pupils, and is thought to be responsible for the crisis of indiscipline in schools (Karanja \& Bowen, 2002; Ngwokabuenui, 2015).

\section{Theory}

This study was based on Kohlberg's (1958) theory which assumes that learning and moral development of pupils move hand in hand. The theory assumes that teachers should aim to assisting learners' progression from the pre-conventional stage of moral development with its concentration on the self and punitive authoritarian discipline strategies to the conventional were empathy for, and the rights of others are emphasized. The theory assumes that behaviour influences the learning of pupils in schools. Kohlberg's theory highlights the applied principles and values rather than mechanically following rules without necessarily realizing the underlying purpose for them. It is also assumed that moral development is achieved in schools by teachers modeling appropriate behaviour and having a school behaviour management plans based on similar principles. The theory presumes that most schools exhibit values and beliefs that are a mix of conventional behavioral patterns and this would be inconsistent in instilling pupils' discipline. The theory assumes that morality starts from the early childhood years of development and improves gradually and proportionally in relation to the pupils' age. 


\section{Models of School Management Mechanisms}

\section{Guidance and counselling}

In primary schools today the pupil to teacher ratio has increased making it hard for teachers to effectively and efficiently manage pupils discipline (O’Brennan, Bradshaw \& Furlong, 2014; Coe, Aloisi, Higgins, \& Major, 2014). This has increased the number of pupils' aggressive behaviours, loitering of pupils during class time which is an indication of violation of school rules and regulations (Sun \& Shek, 2012). This has also brought a challenge of pupils being dismissed from one school but easily admitted into another school. This has made pupils not necessitated to maintain discipline while at school (Mussa, 2015). In the current situation prevailing in upper primary basic level, indiscipline has taken new form to comprise of increased violence, sale and consumption of drugs, theft, disrespect of school rules and regulations which have led to use of corporal punishment, students' expulsion and suspension of pupils from schools (Gershof \& Font, 2016; Bradshaw, Mitchell \& Leaf, 2010; Palaniandy, 2009). Today, pupils spend more time in schools than with parents where they are suspected to get adapted to all kinds of negative behaviour such as homosexuality, smoking, substance abuse, and use of nasty words among other things (Gershof \& Font, 2016; Bradshaw, Mitchell \& Leaf, 2010; Palaniandy, 2009). It has been observed that with all kinds of behaviour obtained at school, they can be greatly controlled by guidance and counselling provided to pupils at school. With the current status of indiscipline in upper primary basic level today, counselling and guidance should be implemented to restore discipline in the schools.

\section{Rules and regulations}

Schools rules and regulation are among the strategies designed to instil good conduct of students (Ngwokabuenui, 2015). School rules and regulations help pupils to have self-control, orderliness, good behaviour and obedience to school authority. On admission pupils are oriented on what is expected from them (Adams, 2013). The orientation process highlights the rules and regulations the pupils are supposed to follow while at school.

Maingi, Maithya, Mulwa and Migosi (2017) highlighted that to maintain discipline pupils should be controlled through rules and regulations set by schools. He observed that school rules and regulations are enforced through prefects' bodies and councils, disciplinary committees, teachers and involvement of parents. The rules and regulations specify what pupils should do and what they should not do when at school. Despite this expectation, many primary school pupils break rules and regulations to propagate indiscipline acts such as escaping from schools, taking of alcoholic drinks, participating in frequent strikes leading to the closure of schools, and suspension of pupils from schools. It has become normal in many schools for students to break school rules and regulations with impunity, showing lack of respect to school authority, damaging of school property, beating up their teachers, rioting at any slightest opportunity and even inflicting harm on one another. The lack of discipline among primary school pupils interferes with the teaching and learning process (Duda \& Susilo, 2018). This is manifested itself through various ways such as bullying, vandalism, alcohol consumption and substance abuse, truancy, thefts, loss of lives, inability or unwillingness to do class work at home (Kwale, 2017). However, since most school rules and regulations are set without students' participation, this has led pupils to resist them and at times break them leading to indiscipline acts (Maingi, et al., 2017). Setting rules and regulations involving all stakeholders would make the best rules and regulations for pupils in upper primary basic level.

\section{School- family initiative}

Smariga (2007) mentions that a teachers' personality has a great role it plays in the management of discipline among pupils in schools. He says that younger children are attracted by the outer charm and 
repelled by the shabby look of the teacher. The school-family environment would enhance the fathermother relationship where children copy from their parents' good behaviour. Hughes and Kwok, (2007) found that unrest in schools was partly caused by teachers' personality in relation to pupils. Teachers must be presentable and act as role models all the time in simple and smart attires (Sampson, 2016). Fancy dressing makes a teacher centre of attraction and a topic for discussion by pupils. A teacher is being watched and held up as a role model by the scores of children who look up to him for guidance. The school-family environment is desired to enhance the teacher's role as a model to be copied, or be emulated (Okeke, 2014).

Some pupils turn out to behave in awkward ways hence mutilating the valid and valued goals of schools. A teacher is where the strength of an education institution lies and it is unlikely for pupils to get superior education better than that of their teachers (Hughes \& Kwok, 2007). There is no education system that can rise higher than that of its teachers. Nassozi (2010) established that indiscipline had worsened were some parents had literally abandoned their role as moulders of their children. In the same study teachers were also found to have caused indiscipline among pupils by abusing and neglecting their work (Hughes \& Kwok, 2007). They did not observe punctuality and were absent from duty hence portraying a bad school environment that could be copied by the pupils.

\section{Discipline}

School discipline is a product of several factors that are embedded within the context of the school environment (Kalagbor, 2016). Discipline is referred to as good behaviour or conduct exhibited by pupils at school, and outside the school. According to Reyes \& Jason (1991) discipline comprises of instructions a person has to follow and adheres to it under given premises. Discipline entails enforcement of order to ensure that instructions are carried out effectively and efficiently. In primary schools there are apparent significances of non-conformity to school rules and regulations that include petty theft, fighting, early age sexual activities, alcohol consumption, cigarette smoking and irregular attendance of pupils among others. Such indiscipline cases exhibited by the children have led to disruptions in schools with instances of strikes and fights among the pupils (Kilonzo, 2013).

Discipline is most associated with the notion of bringing children into line (Skiba \& Peterson, 2003), and how teachers accomplish their duties in order for the children learn, grow and develop well. Without disciplinary measures schools cannot function well towards the achievement of their goals (Skiba \& Peterson, 2003). Uncontrolled discipline in schools might require all stakeholders' involvement using school management mechanisms to meet the needs of their pupils, and manage disruptive behaviour in schools (Kyle \& Rogien, 2004; INTO, 2004). In primary schools where $360^{\circ}$ implementation of school management mechanisms has been observed that discipline among pupils prevails all the time. This study examined whether school management mechanisms have an effect on discipline of pupils in schools. The study tested the following hypotheses;

1. There is no statistically significant effect of guidance and counseling on the discipline of pupils in upper primary basic level.

2. There is no statistically significant effect of school rules and regulations on the discipline of pupils in upper primary basic level.

There is no statistically significant effect of school-family initiatives on the discipline of pupils in upper primary basic level. 


\section{METHOD}

The following methods were employed in the collection and analysis of data for this study.

\section{Study Design}

A cross sectional survey design using both quantitative and qualitative approaches was employed to obtain data for the study. A cross sectional design was used because the study was collecting data from various categories of people at the same point in time. Qualitative data was collected to triangulate the quantitative data collected for this study (Creswell, 2014).

\section{Study Population}

The study population included teachers, chairperson of school disciplinary committees, prefects' bodies and pupils. Teachers implement guidance and counseling to the pupils, prefects lead their fellow pupils and pupils' discipline was the subject matter under study in the primary schools, upper basic level. The population was from 11 primary schools in Bweyale Town Council, central Uganda from both the public and private schools. The total population of participants was 1322 across the various categories.

\section{Sample Size and Sampling Technique}

The researcher selected participants from 9 primary schools out of 11 schools which were selected randomly. A total of 349 respondents were selected from a target population of 1322 . The sample size was determined using the Krejice and Morgan (1970) sample determination table, as seen in Table 1.

Table 1

\begin{tabular}{llll} 
Sample Size and Sampling Methods & & & \\
\hline Employee Category(ies) & Population & Sample Size & Sampling Method \\
\hline Teachers & 11 & 9 & Census \\
Chair-person disciplinary committees & 11 & 9 & Census \\
Pupils (P3-P7) & 1121 & 291 & Stratified random \\
School prefects & 40 & 40 & Census \\
Total & 1322 & 349 & \\
\hline
\end{tabular}

Source: Field data, 2018

\section{Data Collection Tools}

Three instruments of data collection were used to collect data; self-administered questionnaires, interview-guide and FGD-guide.

\section{Questionnaire}

A questionnaire was developed based on a 5 point Likert scale model were; $1=$ strongly disagree, $2=$ disagree, $3=$ neither agree nor disagree, $4=$ agree and $5=$ strongly agree. The questionnaire was structured into five (5) sections; bio data of the respondent, guidance and counselling practice, school rules and regulations, school-family initiative and discipline of the pupils. This questionnaire was administered among pupils from primary five to primary seven in selected primary schools. This was the case because pupils in the lower classes could not appropriately read and write.

\section{Interview guide}

Face to face interviews were conducted with key informants who were teachers and chair-person school disciplinary committee. The interviews were conducted at the schools using unstructured 
interviews with the questions. The interviews were used to attain in-depth data on various dimensions of the study.

\section{Focus group discussion guide}

Focus group discussion guide was used to collect qualitative information from school prefects. The prefects were engaged in focus group discussions to have shared interaction of ideas and resolutions on issues raised during the discussions. Pupils have immediate and firsthand information on their fellow pupils' discipline.

\section{Validity and Reliability}

\section{Validity}

The validity of the instrument was established using both the construct and content validity. The validity of the instrument was obtained through experts who assessed items in the questionnaire, interview schedule and focus group discussion guide to verify if they were relevant to collect data for the study. After the expert validation of the instrument for the content validity it was determined that the instruments used were valid. Content validity indices of $0.891, .883$ and .771 were derived for the questionnaire, interview guide and focus group discussion guide, respectively. This implied that the instruments used for this study were valid since all the content validity indices obtained were greater than 0.7 . According to Amin (2005) content validity index greater than 0.7 reflects a good instrument and appropriate to collect data for the study.

\section{Reliability}

The reliability index was used to determine the internal consistency of the instrument, and its predicted performance in the study were it would be used. In this study the reliability of the questionnaire was assessed using the Cronbach's Alpha. This was obtained through conducting a pilot study and the data was analysed using SPSS to compute the reliability of the instrument. Results obtained were adequate (0.823) which confirmed that the questionnaire would be consistent when used to collect data for the study.

\section{Data Processing}

After data was collected it was sorted, coded and captured using a carefully designed data entry screen which was developed and customized using SPSS. After data entry a thorough data cleaning process was performed; outliers were identified and fixed accordingly.

\section{Data Analysis}

\section{Quantitative data}

Data analysis was performed in the SPSS (Version 20) application where, descriptive statistics were generated for continuous variables while for categorical variables, frequencies, and percentages were generated. Pearson correlation product moment correlation and multiple regression analysis were used to test the hypotheses and to determine the single most predicting variables that is related to pupils' discipline.

\section{Qualitative data}

Qualitative data for interviews and focus group discussions was transcribed verbatim, correctness of transcription was conducted; minor corrections, particularly grammatical errors and incomplete responses to the questions were corrected and triangulated with quantitative data based on the study objectives. Qualitative analysis was done using the thematic content analysis. 


\section{FINDINGS}

This section contains analysis of bio-data and testing of hypotheses for the study.

Table 2

Gender of Upper basic Pupils

\begin{tabular}{|c|c|c|c|}
\hline Item & Categories & Frequency & Percent \\
\hline \multirow[t]{3}{*}{ Gender } & Male & 143 & 49.1 \\
\hline & Female & 148 & 50.9 \\
\hline & Total & 291 & 100.0 \\
\hline \multirow[t]{3}{*}{ Age } & Less than 12 years & 144 & 49.5 \\
\hline & 12 years and above & 147 & 50.5 \\
\hline & Total & 291 & 100.0 \\
\hline
\end{tabular}

According to the demographic characteristics shown in Table 2 the majority of the respondents were females; $148(50.9 \%)$, and males were $143(49.1 \%)$. Also, 147(50.5\%) were aged above 12 years while $144(49.5 \%)$ were less than 12 years of age. This implies that both genders were catered for in the study, and were also from various age groups. On the question of having guidance and counselling services in upper primary basic level it was observed that it existed as seen in Table 3 below

Table 3

My School has Guidance and Counseling Services for Upper basic Pupils

\begin{tabular}{lll}
\hline \multicolumn{1}{r}{ Responses } & Frequency & Percent \\
\hline Strongly disagree & 18 & 6.2 \\
Disagree & 29 & 10.0 \\
Neutral & 51 & 17.5 \\
Agree & 110 & 37.8 \\
Strongly agree & 83 & 28.5 \\
Total & 291 & 100.0 \\
\hline
\end{tabular}

Table 4

Rules and Regulations Apply to All Pupils

\begin{tabular}{lll}
\hline \multicolumn{1}{c}{ Responses } & Frequency & Percent \\
\hline Strongly disagree & 6 & 2.1 \\
Disagree & 17 & 5.8 \\
$\begin{array}{l}\text { Neither agree nor } \\
\text { disagree }\end{array}$ & 27 & 9.3 \\
Agree & & \\
Strongly agree & 105 & 36.1 \\
Total & 136 & 46.7 \\
\hline
\end{tabular}

According to the descriptive results in Table 3 regarding to whether schools had guidance and counseling services for upper basic pupils, it was discovered that $110(37.8 \%)$ of the respondents agreed and $83(28.5 \%)$ strongly agreed in the same category. Also, 51(17.5\%) neither agreed nor disagreed, 29(10.0\%) disagreed, and 18(6.2\%) strongly disagreed. The results in Table 3 highlight that majority of the respondents were in agreement (193(66.3\%)) that counseling and guidance services existed in upper primary basic level. With rules and regulations affecting the discipline of students in upper primary basic level $105(36.1 \%)$ of the respondents agreed while $136(46.7 \%)$ strongly agreed that rules and regulations in schools apply to all pupils in upper primary basic level. This indicates that primary schools have rules and regulations to address disciplinary issues among pupils in upper 
primary basic level. According to the questions that attested to whether school-family initiative programmes existed in schools revealed the following results below;

Table 5

This School has a Family Initiative Programmes

\begin{tabular}{lll}
\hline Responses & Frequency & Percent \\
\hline Strongly disagree & 12 & 4.1 \\
Disagree & 31 & 10.7 \\
Neither agree nor disagree & 51 & 17.5 \\
Agree & 81 & 27.8 \\
Strongly agree & 116 & 39.9 \\
Total & 291 & 100.0 \\
\hline
\end{tabular}

In the results highlighted in Table 5 it was discovered that family-initiative programmes were in place in the selected schools and were used in intervening pupils' discipline. It was discovered that $116(39.9 \%)$ respondents strongly agreed, $81(27.8 \%)$ of the respondents agreed. 51(17.5\%), $31(10.7 \%), 12(4.1 \%)$ respondents neither agree nor disagree, disagree and strongly disagree, respectively. As the respondents in agreement were more than those in disagreement this means that primary schools have family initiatives programmes used as a mechanism to curb indiscipline among pupils in upper basic levels.

Table 6

Pearson Product Moment Correlation between Counselling and Guidance, School Rules and Regulations, School-Family Initiative and Discipline among Pupils

\begin{tabular}{lllll}
\hline No. & & Discipline & \\
\hline & & Pearson Correlation & Sign (2-tailed) & N \\
\cline { 3 - 5 } 1 & Counselling and guidance & 0.628 & .000 & 291 \\
2 & School rules and regulations & 0.678 & .000 & 291 \\
3 & School-family initiative & 0.604 & .000 & 291 \\
\hline
\end{tabular}

Correlation is significant at the 0.05 level (2-tailed), $\mathrm{N}=$ Sample

Table 6 shows that there is a positive and statistically significant relationship between counseling and guidance and discipline among pupils $(r=0.628$; $p$-value, $0.00<0.05 ; 95 \%)$. This implies that there is a relationship between counseling and guidance and discipline of pupils in upper primary basic level. It was also noted that school rules and regulations and discipline were statistically significantly related $(\mathrm{r}=0.678 ; \mathrm{p}$-value, $0.000<0.05 ; 95 \%)$, and the null hypothesis was rejected. The results of school family-initiatives and discipline among pupils showed that the two variables are statistically significantly related $(\mathrm{r}=0.604$, p-value, $0.00<0.05,95 \%)$. This implies that school family initiatives have a positive and statistically significant relationship with discipline among pupils in upper primary basic level.

Table 71

Multiple Regression Analysis for School Management Mechanisms and Discipline among Pupils

\begin{tabular}{|c|c|c|c|c|c|c|c|c|c|}
\hline \multirow[t]{2}{*}{ Model } & \multirow[t]{2}{*}{$\mathrm{R}$} & \multirow{2}{*}{$\begin{array}{l}\mathrm{R} \\
\text { Square }\end{array}$} & \multirow{2}{*}{$\begin{array}{l}\text { Adjusted R } \\
\text { Square }\end{array}$} & \multirow{2}{*}{$\begin{array}{l}\text { Std. Error of the } \\
\text { Estimate }\end{array}$} & \multicolumn{5}{|c|}{ Change Statistics } \\
\hline & & & & & $\begin{array}{l}\text { R Square } \\
\text { Change }\end{array}$ & $\begin{array}{l}\mathrm{F} \\
\text { Change }\end{array}$ & df1 & df2 & $\begin{array}{l}\text { Sig. F } \\
\text { Change }\end{array}$ \\
\hline 1 & $.628^{\mathrm{a}}$ & .813 & .890 & .35232 & .871 & 224.672 & 1 & 98 & .003 \\
\hline 2 & $.671^{\mathrm{b}}$ & .902 & .823 & .31767 & .016 & 12.403 & 1 & 81 & .009 \\
\hline 3 & $.601^{\mathrm{c}}$ & .867 & .845 & .38267 & .028 & 21.946 & 1 & 60 & .004 \\
\hline
\end{tabular}

a. Predictors: (Constant), Counselling and Guidance

b. Predictors: (Constant), School Rules and Regulations

c. Predictors: (Constant), School-Family Initiative 
The multiple regression results in Table 7 reflect that counselling and guidance was statistically related to discipline among pupils $(r=.628 ; \mathrm{p}$-value, $0.003<0.05 ; 95 \%)$. This highlights that a unit change in counselling and guidance brings about $62.8 \%$ in the pupils' discipline in upper primary basic level. Other results indicate that school rules and regulations are related to discipline among pupils $(\mathrm{r}=.671$; p-value, $0.009<0.05 ; 95 \%$ ). The results highlight that a unit change in school rules and regulations brings about $67.1 \%$ in the pupils' discipline in upper primary basic level. This was the single most predicting factor to improvement of pupils' discipline among the variables studied. In other results it was revealed that school-family initiative and discipline among pupils are statistically related to discipline among pupils in upper primary basic level $(\mathrm{r}=.601$; $\mathrm{p}$-value, $0.04<0.005$; 95\%). The results highlight that a unit change in school-family initiative brings about $60.1 \%$ in the pupils' discipline in upper primary basic level. This was the least predicting factor to pupils' discipline among the variables studied. The results reveal that all the three variables (counselling and guidance, school rules and regulations and school-family initiative) studied predict pupils discipline in upper primary basic level.

\section{DISCUSSION}

Guidance and counseling and discipline among pupils in upper primary basic level were statistically related. This means that increased counseling and guidance to pupils leads to improved pupils' discipline in primary schools (O’Brennan, Bradshaw \& Furlong, 2014; Afande, 2015; Salgong, Ngumi \& Chege, 2016). Acording to Nasilumbi, Munyau and Tarus (2016) the results imply that as counselling and guidance increases among upper basic pupils, their being discipline in schools, and outside the school increases. From the FGD conducted with prefects, it was found out that guidance and counseling was offered to pupils in primary schools. The pupils in the primary schools had good knowledge about its meaning and the importance of offering counseling and guidance to pupils in the school setting. One prefect in a public primary school noted that counseling and guidance had helped many pupils to discover themselves, and their behaviors had changed positively.

"Counseling and guidance has helped us to be good pupils at school without parents" (Religious affairs prefect).

It was also found that through offering counseling and guidance to pupils, the behavior among pupils improved as this was revealed by one head prefect from one primary school. It was revealed that such had improved pupils' conduct in terms of communicating with other people including fellow pupils in the school.

"Due to guidance and counselling many pupils' communication skills have improved and also behave well with teachers, school employees and parents as well” (Head boy).

According to the information from one of the teachers during the interview he revealed that guidance and counseling was given to individual pupils who had personal problems. However, it would also be given to groups or the entire school especially during the school assembly times. According to the class teacher, P.7 it was noted that;

"We offer guidance and counseling to our pupils at all times in different forms and according to numbers of pupils. This has greatly changed their discipline” (Class teacher, P7).

School rules and regulations had a positive and statistically significant relationship with discipline among pupils in primary schools. Obtaining better outcomes in terms of discipline among pupils requires a boost from well-designed school rules and regulation to meet the purpose (Wagner \& Ruch, 2015; Blazar \& Kraft, 2017). The results agree with the literature by Mussa (2015) who argued that over time the pupils to teacher ratio will increase and make it hard for teachers to effectively and efficiently manage pupils discipline. This would increase the number of pupils' aggressive behaviors, 
loitering of pupils during class time and increase in the of violation of school rules and regulations. Having in place frugal, sound and operational school rules and regulations would greatly reduce pupils' misbehavior in primary schools (Sun \& Shek, 2012).

Karambu (2012) conquers with O'Connor \& McCartney (2007) and believes that responsiveness to rules and regulations can become a consequence of how school managers or leaders view them. INTO (2004) carried out a study on discipline among learners in a state funded school and established that failure to implement rules and regulations leads to the collapse of discipline in schools. Gershof and Font (2016) who carried out a study on the level of discipline in schools in Niger found wide spread violation of school rules and regulations. It was discovered that the violation of school rules and regulations was associated with obstructing the smooth and orderly functioning of school systems.

Kelly (2003) argues that efficient use rules and regulations in terms of time management on the part of the pupils and school administrators it is directly associated with increased academic performance. Mussa (2015) also concurs and further explains that extra time study as part of discipline management has a strong influence on academic attainment of pupils. Eilam (2003) stresses that time management can be viewed as a way monitoring and regulating oneself with regard to the performance of multiple tasks within a certain time period. Hattie (2003) had earlier concluded that success that is discipline oriented could be achieved in schools when teachers showed good time management. From the FGD it was noted that school rules and regulations are adhered to by pupils, and this has led to more disciplined pupils in the school. However, it was mentioned that some rules and regulation are harsh to them since bleaching them would lead to expulsion from school, or serve heavy punishments. A prefect revealed;

"Some pupils in p5-p7 classes feel that they are mature and when they bleach some rules and regulations they are expelled from school, or serve heavy punishments" (Sanitary prefect).

O'Connor \& McCartney (2007) also argued that the best results could be obtained through vigilantly reminding students about rules and regulations of the school, and monitoring their compliance with them. It has become normal in many schools for students to break school rules and regulations with impunity, showing lack of respect to school authority, damaging of school property, beating up their teachers, rioting at any slightest opportunity and even inflicting harm on one another. The consequences from such undisciplined behaviors may result into poor students' performance (Ndeto, 2016).

In this study it was discovered that there is a positive and statistically significant relationship between school-family initiatives and discipline of pupils in primary schools. It is highlighted that the increased implementation of school-family initiatives increases discipline among pupils. This is due to the fact that teachers and parents play a bigger role in streamlining behaviors of pupils at school and home. This is in line with Wood and Bauman (2017), Dwyer and Hecht (1992), and El-Nokali, Bachman and Votruba-Drzal (2010) who assert that a pupil may have no room of undisciplined behaving since the entire environment in which he/she interacts is encouraging discipline. Most un-rest in schools are due to poor teachers-student relationships, or rather a poor or bad school-family environment (Hughes \& Kwok, 2007). Fontana (2007) noted that students are hurt when they realize that they are constantly ignored by people who have an important role to play in their lives like parents and teachers. Hughes and Kwok (2007) was interested in family and school influence on students' discipline to which he established that teacher-student relationships have an effect on students' discipline. Montgomery and Kehoe (2016) found out that on occasions where the school failed to teach appropriate content to children or even failed to use appropriate instructional materials students had become frustrated and unsettled and thus becoming undisciplined. 
Karambu (2012) on the other hand mentioned that lack of democratic leadership in schools together with communication breakdown are the major causes of indiscipline. This highlighted the there was a missed link in communication between the guardians of pupils and the school management. He noted that there is a relationship between school-family initiative and discipline among pupils in primary school. According to MoES (2011) it was noted that some students who do not fully focus on academics do not value family togetherness with the school. Jones and Jones (2006) highlighted that schools have not fully adapted to pupils' non-academic needs. This has made teachers tend to be examination oriented not knowing that the implementation of the curriculum does not cater for holistic development of the pupils.

Mutua (2004) in her study on student unrests and indiscipline in schools reported that discipline is considered vital for students' academic and social success. A good academic qualification without a good foundation of discipline of the individuals is of no use to the individuals, their families and society. According to Akala (2000) students and teachers in schools affected by unrest find it difficult to restore working relationship after the unrest. The emotional and psychological trauma that is characterized with the aftermath of pupils' unrest strains further interactions among the pupils and other education stakeholders.

Akala (2000) states that if a school has effective discipline management mechanisms the pupils' academic performance will be good. For this reason, the teachers have an awesome responsibility of not only teaching effectively, but also ensure discipline among pupils (Akala, 2000; Okeke, 2014). From the FGD one participants revealed that school-family initiative has enabled pupils to build trust and be open in communication. She further noted that this initiative has helped many pupils to know how to express themselves which reflects discipline when speaking to people.

"School-family initiative has promoted appropriate speaking among pupils for they can talk freely with teachers and parents thus promoting discipline" (Teacher, P.6).

In one school a prefect noted that the school-family initiative had led to positive behavior change among pupils and this was reflected in the manner pupils related with fellow pupils, teachers and other elders.

"We as pupils, we have acquired behavior change from school-family initiative and we thank the school for the program" (Head prefect).

\section{CONCLUSION AND RECOMMENDATIONS}

From the findings of this study it is concluded school rules and regulations, counselling and guidance, and school-family initiative control pupils discipline in upper basic level in primary school. It is also recommended from the results that schools should execute more guidance and counselling to pupils to enforce good behaviour as it had the highest effect on pupils' discipline. This should be done by teachers who are experts in guidance and counselling to be more effective. The school management should put more emphasis on proper implementation of school rules and regulations, as well as consistent monitoring of pupils' compliance with the rules and regulations in avid to improve their discipline. This is due to the fact that it has showed a strong and positive relationship with discipline among pupils. Parents should be more committed to discipline of their children through proper supervision and guidance of children at home.

\section{REFERENCES}

Afande, F. O. (2015). Effect of guidance and counselling on pupils in public primary schools in Makadara Division of Nairobi province. Research on Humanities and Social Sciences, 5(5), 63-77. 
Akala, W. J. (2000). A long history of pupils' discontent and strikes. Daily Nation. Retrieved from https://www.nation.co.ke/lifestyle/1190-364152-fe4i03z/index.html.

Amin, M. E. (2005). Social science research; Conception, methodology and analysis. Kampala: Makerere University.

Blazar, D., \& Kraft, M. A. (2017). Teacher and teaching effects on students' attitudes and behaviors. Educational Evaluation and Policy Analysis, 39(1), 146-170. https://doi.org/10.3102/0162373716670260.

Bradshaw, C. P., Mitchell, M. M., \& Leaf, P. J. (2010). Examining the effects of school wide positive behavioural interventions and supports on student outcomes: Results from a randomized controlled effectiveness trial in elementary schools. Journal of Positive Behavior Interventions, 12, 133-148. https://doi.org/10.1177/1098300709334798.

British Council (2010). Inclusion and diversity in education: Guidelines for inclusion and diversity in schools. Retrieved from https://www.britishcouncil.es/sites/default/files/british-council-guidelines-forinclusion-and-diversity-in-schools.pdf.

Coe, R., Aloisi, C., Higgins, S., \& Major, L. E. (2014). What makes great teaching? Review of the underpinning research. Retrieved from https://www.suttontrust.com/wpcontent/uploads/2014/10/What-makes-great-teaching-FINAL-4.11.14.pdf.

Creswell, J. W. (2014). Research design: Qualitative, quantitative and mixed method approaches. Sage.

Daggett, B. (2014). Addressing current and future challenges in education: Lessons learned from the nation's most rapidly improving and transformative schools. 22nd annual model schools conference. International Center for Leadership in Education. Retrieved on $29^{\text {th }}$ December, 2018 from http://www.leadered.com/pdf/2014MSC_AddressingCurrentandFutureChallenges.pdf.

De la Iglesia, G., \& Castro-Solano, A. (2018). The positive personality model: Exploring a new conceptual framework for personality assessment. Frontiers in Psychology, 9, 2027. https://doi.org/10.3389/fpsyg.2018.02027

De Witt, M. W., \& Lessing, A. C. (2013). Teachers' perceptions of the influence of learners' undisciplined behaviour on their working life and of the support of role-players. Koers - Bulletin for Christian Scholarship, 78(3), 458-467. http://dx.doi.org/10.4102/ koers.v78i3.458

Dickinson, P. (2001). Guidelines for mentally healthy schools: a resource to assist schools in the implementation of mental health promotion initiatives in the school community. New Zealand: Mental Health Foundation.

Donovan, P. (1998). School-based sexuality education: the issues and challenges. Perspectives on Sexual and Reproductive Health, 30(4), 188 - 193.

Duda, H. J., \& Susilo, H. (2018). Science process skill development: Potential of practicum through problems based learning and authentic assessment. Anatolian Journal of Education, 3(1), 51-60.

Duncan-Williams, B. (2015) Academic stress, academic performance and the psychological wellbeing of senior high school remedial students in the greater Accra region of Ghana (Unpublished master thesis). University of Ghana, Ghana.

Dwyer, D. J., \& Hecht, H. B. (1992). Causes underlying minimal parent involvement in the education of their children. School Community Journal, 2(2), 275 - 290. 
Eilam, B., \& Aharon, I. (2003). Students planning in the process of self-regulated learning. Cont. Educational Psychology, 28(3), 304-334. https://doi.org/10.1016/S0361-476X(02)00042-5.

El-Nokali, N. E., Bachman, H. J., \& Votruba-Drzal, E. (2010). Parent involvement and children's academic and social development in elementary school. Child Development, 81(3), 988-1005. https://doi.org/10.1111/j.1467-8624.2010.01447.x.

Fontana, D. (2007). Class control: Understanding and guiding classroom behavior. Leicester London: The British Psychological Society.

Gershoff, E. T., \& Font, S. A. (2016). Corporal punishment in u.s. public schools: Prevalence, disparities in use, and status in state and federal policy. Social policy report, 30, 1. https://doi.org/10.1002/j.2379-3988.2016.tb00086.x.

Gyan, E., Baah-Korang, K., Mccarthy, P., \& Mccarthy, P. (2015). Causes of indiscipline and measures of improving discipline in senior secondary schools in Ghana: Case study of a senior secondary school in Sunyani. Journal of Education and Practice,6(11), 19-25.

Hattie, J. A. C. (2003). Teachers make a difference: What is the research evidence? Paper presented at the building teacher quality: What does the research tell us ACER Research Conference, Melbourne, Australia. Retrieved from http://research.acer.edu.au/research_conference_2003/4/.

Hughes, J., \& Kwok, O. M. (2007). Influence of student-teacher and parent-teacher relationships on lower achieving readers' engagement and achievement in the primary grades. Journal of Educational Psychology, 99(1), 39-51.

Irish National Teachers' Organization [INTO] (2004). Managing challenging behavior: Guidelines for teachers. Irish national teachers' organization. Retrieved from https://www.into.ie/ROI/Publications/ManagingChallengingBehaviour.pdf.

Irkhin, V. N., \& Bogacheva, E. A. (2015). Management mechanisms of the health oriented educational system development: By the example of belgorod region schools. Pedagogy of Health, 4(6), 23-28. https://doi.org/10.18413/2313-8971-2015-1-4-23-28.

Jones, V. F., \& Jones, L. S. (2006). Comprehensive Classroom Management: Creating Positive Learning Environment for all Students. Boston: Allyn and Bacon.

Kalagbor, L. D. (2016). An analysis of factors influencing students' academic performance in public and private secondary schools in rivers state Nigeria. J. of Education and Practice, 7(28), 96-101.

Karambu, M. J. (2012). Disciplinary problems faced by teachers in primary schools: A study of selected primary schools in South Imenti of Meru Central District (Unpublished master thesis). http://ir-library.ku.ac.ke/handle/123456789/2806.

Karanja, R., \& Bowen, B. (2002). Student indiscipline and academic performance in public schools in Kenya: Daystar University Centre for research and publications working paper series. Retrieved from https://www.daystar.ac.ke/downloads/working-papers/Working\%20Paper\%20002.pdf.

Karuri, S. W. (2015). Factors influencing pupils' discipline in public primary schools in Dagoretti Sub-County Nairobi, Kenya (Unpublished master thesis). University of Nairobi.

Kelly, W. E. (2003). As achievement sails the river of time: The role of time use efficiency in GradePoint-Average. Educational Research Quarterly, 27(4), 3-8.

Kilonzo, J. (2013). Challenges faced by head teachers in the management of students' indiscipline in public secondary schools in Lamu County (Unpublished master thesis). Kinyatta University, Kenya. 
Kohlberg, L. (1958). The development of modes of thinking and choices in years 10 to 16 (Unpublished doctoral dissertation). University of Chicago.

Korpershoek, H., Harms, T., de Boer, H., van Kuijk, M., \& Doolaard, S. (2014). Effective classroom management strategies and classroom management programs for educational practice: a metaanalysis of the effects of classroom management strategies and classroom management programs on students' academic, behavioral, emotional, and motivational outcomes. Groningen: RUG/GION.

Krejcie, R., \& Morgan, D. (1970). Determining sample size for research activities. Educational and Psychological Measurement, 30, 607-610.

Kwale, A. J. (2017). Factors leading to indiscipline in secondary schools in Siha District Council, Tanzania. Retrieved from http://repository.out.ac.tz/2165/1/DISSERTATION\%20ALOYCE\%20JOHN\%20KIWALE.pdf

Kyle, P., \& Rogien, L. (2004). opportunities and options in classroom management. Boston: Allyn \& Bacon.

Maingi, D., Maithya, R., Mulwa, D., \& Migosi, J. (2017). Influence of school rules' formulation on students' discipline in public secondary schools in Makueni County. International Journal of Humanities and Social Science Invention, 6(1), 1-6.

Mather, N., \& Goldstein, S. (2001). Learning disabilities and challenging behaviors: A guide to intervention and classroom management. Baltimore: Paul H. Brookes Publishing.

Montgomery, A., \& Kehoe, I. (2016). reimagining the purpose of schools and educational organizations: Developing critical thinking, agency, beliefs in schools and educational organizations. Switzerland: Springer International Publishing.

Mussa, L. (2015). The role of school discipline on students' academic performance in Dar es Salaam, Tanzania (Unpublished master thesis). Tanzania, University of Tanzania.

Mutua, J. N. (2004). Investigation into alternative strategies of discipline in the absence of corporal punishment in public secondary schools (Unpublished master thesis). Nairobi, University of Nairobi.

Nasilumbi, W. J., Munyau, K. J., \& Tarus, P. (2016). Teachers' demographic factors on attitude towards guidance and counselling services in public primary schools of Kimilili Sub-county, Kenya. Journal of Education and Practice, 7(31), 39 - 47.

Nassozi, I. (2010). The effect of teachers' leadership role on students' discipline in secondary schools in Wakiso District (Unpublished master thesis). Uganda, Makerere University.

Ncontsa, V. N., \& Shumba, A. (2013). The nature, causes and effects of school violence in South African high schools. South African Journal of Education, 33(3), 1-15.

NCSE (2013). Supporting students with special educational needs in schools. NCSE Policy advice paper NO. 4.4 Retrieved http://ncse.ie/wpcontent/uploads/2014/09/Supporting_14_05_13_web.pdf.

Ndeto, A. M. (2016). Effectiveness of school rules and regulations in enhancing discipline in public secondary schools in Kangundo Division, Machakos county, Kenya (Unpublished master thesis). Kenya, The Catholic University of Eastern Africa.

Ngwokabuenui, P. Y. (2015). Students' indiscipline: Types, causes and possible solutions: The case of secondary schools in Cameroon. Journal of Education and Practice, 6(22), 64 - 72. 
Nooruddin, S., \& Baig, S. (2014). Student behavior management: School leader's role in the eyes of the teachers and students. International Journal of Whole Schooling, 10(2), 1-20.

Nzoka, J. T., \& Orodho, J. A. (2014). School management and students' academic performance: How effective are strategies being employed by school managers in secondary schools in Embu North District, Embu County, Kenya? International Journal of Humanities and Social Science, 4(9), 86-99.

O’Brennan, L. M., Bradshaw, C. P., \& Furlong, M. J. (2014). Influence of classroom and school climate on teacher perceptions of student problem behavior. School Mental Health, 6(2), 125-136. https://doi.org/10.1007/s12310-014-9118-8

O'Connor, E., \& McCartney, K. (2007). Study of early child care and youth development. Education Research and Development (NICHD), New York University.

Ofori, K. N., Tordzro, G., Asamoah, E., \& Achiia, E. (2018). The effects of indiscipline on academic performance of junior high school students in the Fanteakwa District of Ghana. Journal of Education and Practice, 9(21), 109-117.

Okeke, C. I. (2014). Effective home-school partnership: Some strategies to help strengthen parental involvement. South African Journal of Education, 34(3), 1 - 9.

Orpinas, P., \& Horne, A. M. (2004). A teacher-focused approach to prevent and reduce students' aggressive behavior: The great teacher program. American J. of Preventive Medicine, 26(1), 29-38.

Palaniandy, S. (2009). A study of student perceptions of teacher characteristics and its influence upon the management of student behaviour in four Malaysian secondary schools. United Kingdom, University of Leicester. from http://citeseerx.ist.psu.edu/viewdoc/download?doi=10.1.1.842.6268\&rep=rep1\&type=pdf

Parsonson, B. S. (2012). Evidence-based classroom behaviour management strategies. Kairaranga, 13(1), 16-23.

Redempta, E. N. (2010). Methods used to enhance students discipline in public secondary schools in Kamukunji division Nairobi province, Kenya (Unpublished master thesis). Kenyatta University.

Reid, G. (2009). Effective learning and motivation: Ideas and strategies for independent learning. Retrieved from https://www.drgavinreid.com/wp-content/uploads/2013/07/GR_article2_motivation.pdf.

Reyes, O., \& Jason, L. A. (1991). An evaluation of a high school dropout prevention program. Journal of Community Psychology, 19(3), 221-230.

Salgong, V. K., Ngumi, O., \& Chege, K. (2016). The role of guidance and counseling in enhancing student discipline in secondary schools in Koibatek District. Journal of Education and Practice, $7(13), 142-151$.

Smariga, M. (2007). Visitation with infants and toddlers in foster care: What judges and attorneys need to know. Retrieved from https://www.americanbar.org/content/dam/aba/administrative/child_law/visitation_brief.pdf.

Sampson, E. C. (2016). Teachers' perceptions of the effect of their attire on middle-school students' behavior and learning (Unpublished doctoral dissertation). Walden University.

Skiba, R., \& Peterson, R. (2003). Teaching the social curriculum: School discipline as instruction, preventing school failure. Alternative Education for Children and Youth, 47(2), 6673. https://doi.org/10.1080/10459880309604432. 
Sun, R. C. F., \& Shek, D. T. L. (2012). Student classroom misbehavior: An exploratory study based on teachers' perceptions. The Scientific World Journal, 1 - 8. https://doi.org/10.1100/2012/208907.

UNESCO \& UNICEF (2007). A human rights-based approach to education for all. A framework for the realization of children's right to education and rights within education. New York, USA.

United Nations Educational, Scientific and Cultural Organization [UNESCO] (2009). Policy guidelines on inclusion in education. Paris, France. Retrieved from http://unesdoc.unesco.org/images/0017/001778/177849e.pdf.

Wagner, L., \& Ruch, W. (2015). Good character at school: positive classroom behavior mediates the link between character strengths and school achievement. Frontiers in Psychology, 6, 610. https://doi.org/10.3389/fpsyg.2015.00610

Wood, L., \& Bauman, E. (2017). How family, school, and community engagement can improve student achievement and influence school reform: Literature review. American Institute for Research (AIR), Washington, DC, SA. 